\title{
Economic-Financial Metanalysis of Termination of Nellore Cattle in Feedlot in Brazil
}

\author{
Felipe Araújo Oliveira da Silva \\ Universidade Federal do Maranhão, UFMA, campus de Chapadinha, Maranhão-Brazil. \\ E-mail: felipezoo25@outlook.com
}

\section{Ricardo Alves de Araújo (Corresponding author)}

Professor, Universidade Estadual do Maranhão, Itapecuru mirim, Maranhão-Brazil.

E-mail: ricardo_zoo@hotmail.com

Luiza de Nazaré Carneiro da Silva

Universidade Federal do Tocantins, UFT, campus de Araguaína, Maranhão-Brazil.

E-mail: luiza.zootecnia@gmail.com

Edmilson Igor Bernardo Almeida

Universidade Federal do Maranhão, UFMA, campus de Chapadinha, Maranhão-Brazil.

E-mail: edmilson_i@ hotmail.com

Clésio dos Santos Costa

Universidade Federal do Ceará, UFC, campus do Pici, Ceará-Brazil.

E-mail: clesiosantzoo@gmail.com

Francisco Naysson de Sousa Santos

Universidade Federal da Paraíba, UFPB, campus de Areia, Paraíba-Brazil.

E-mail: nayssozootecnista@gmail.com

Rosane Cláudia Rodrigues 


\title{
Macrothink

Universidade Federal do Maranhão, UFMA, campus de Chapadinha, Maranhão-Brazil.

E-mail: rosanerodrig@gmail.com

Ivone Rodrigues da Silva

Universidade Federal do Piauí, UFPI, campus de Teresina, Piauí-Brazil.

E-mail: ivonerodrigues10@ hotmail.com

\section{Olivan Cunha Almeida}

Universidade Federal do Maranhão, UFMA, campus de Chapadinha, Maranhão-Brazil.

E-mail: olivan.almeida.tec@gmail.com

\section{Jarlyanne Nargylla Costa Souza}

Universidade Federal do Maranhão, UFMA, campus de Chapadinha, Maranhão-Brazil.

E-mail: lyannecsouza46@gmail.com

\section{Diego de Almeida Veras}

Universidade Federal do Maranhão, UFMA, campus de Chapadinha, Maranhão-Brazil.

E-mail: verasdiego27@gmail.com

Received: July 5, 2020

doi:10.5296/jas.v8i4.17305
Accepted: August 23, 2020

Published: Sep. 1, 2020

URL: https://doi.org/10.5296/jas.v8i4.17305

\begin{abstract}
This study aimed to evaluate the economic and financial viability of the creation of Nellore cattle in feedlot in Brazil. To do so, we performed a meta-analysis of productive data of Brazilian research published in the last ten years, and before the data, simulated to economic analysis. Three scenarios were simulated, the first according to projections of commodity prices, the second with a reduction of $10 \%$ of those prices and the third with an increase of $10 \%$. In first scenario the termination provided positive net income, with total factor productivity (TFP) of R $\$ 1.04$. On the other hand, with the increase of $10 \%$ of the costs of production, there is an income and a negative rate of return. On the other hand, with a reduction of $10 \%$ of the costs of production, the system will only 1,289 animals and, at the
\end{abstract}


same time, the TFP shall be 1.16 , with a return rate of $16.32 \%$. We observed payback with values of less than one year, but with an increase of $10 \%$ on the cost with feeding all indicators were negative. Sensitivity analyzes showed that in most scenarios evaluated, only in situations more unfavorable economic performance indicators were not attractive. A meta-analysis of data from the termination of bovine animals shows that, before the current scenario, the price of commodities provides favorable economic indices, but with a negative variation of $10 \%$ on the price of the same, the indicators are to be negative, even with the price of the @ remaining stable.

Keywords: costs of production, livestock, economic viability

\section{Introduction}

In the year 2018 the production of beef in Brazil was around 10.96 million tonnes carcass equivalent (TCE), 12.8\% above 2017. This result is derived from the rearing systems used throughout the national territory. A large part of the cattle reared in Brazil is of Nelore breed or Anelorados, who passed through an intense genetic improvement in order to achieve satisfactory results for the production of meat (Abiec, 2018).

Brazil is configured as a major producer of beef, having as characteristic of production, animals from pastures, having a competitiveness of the livestock areas with agriculture. However, opening up new areas has stopped due to environmental issues, laws and trade. Allied to this, the forage production is characterized by a seasonality of production, which provides food concentration at certain times of the year. The confinement may be used as an integrated technology to other phases of the system, providing indirect benefits within a system of full cycle, or as isolated technology, i.e., aiming to take advantage of the direct benefits.

The termination of cattle in feedlot has numerous advantages, because it allows you to provide a supply of finished animals throughout the year, reducing the pressure on the pastures during the dry period and reduces the age of slaughter (Santos et al., 2014; Santos et al., 2015).

Know the costs of production of the livestock of cut allows the producer to concentrate a planning and control livestock in their midst. The rural activity as any other, requires financial knowledge and specific monitoring, such as the analysis of costs, which is able to identify the components that exert greater influence in the production of beef. To Lopes \& Carvalho (2002), the economic analysis is the process by which the producer is knowing the financial results of each activity of the company. It is through economic results that the producer can take, consciously, their decisions and face your production system of beef cattle as a company. The economic analysis of cattle activity is important, because currently the Brazilian livestock boasts the largest commercial herd in the world.

Therefore, because of the importance of livestock and the containment system for the country and the world, this research will be conducted using the method of meta-analysis with the aim of obtaining averages of zootechnical parameters and evaluate the indicators of economic-financial analysis of feedlot cattle. 


\section{Material and Methods}

The information of the technical parameters for economic-financial analysis of this research were obtained through a meta-analysis of data published in the last ten years in national journals about the performance of Nelore cattle finished in feedlot in Brazil. The economic and financial evaluation of the data was carried out in a descriptive way, using the Excel ${ }^{\circledR}$ spreadsheets. All costs were simulated for the production of a small containment with capacity of 500 animals.

As the cost of labor, we considered the maintenance of five employees in permanent regime to manage three batches of 500 head per year, with initial body weight of $200 \pm 30 \mathrm{~kg}$ and slaughter weight of $450 \pm 30 \mathrm{~kg}$. Simulated three scenarios, the first according to projections of commodity prices on the world market, the second with a reduction of $10 \%$ of the feeding of animals and the third with an increase of $10 \%$. The productive and zootechnical data used in confinement were based on data from the meta-analysis, using a standard diet based on corn, soybean meal, corn silage, mineral salt and limestone.

In possession of data from the meta-analysis simulated the confinement of animals for an average daily gain of $1,750 \mathrm{~g}$, feed conversion ratio of $6.00 \mathrm{~kg}$, providing a period of confinement of 114.65 days, which allowed to simulate the termination of three batches year ${ }^{-1}$. The economic analysis was based on the calculation of cost of production, which is represented by the sum of all resources (inputs) and operations (services) used in the production process. The variable cost was composed by food, health, labor, equipment maintenance, depreciation and other costs (power of the wielder, specifications on zootechnics and electrical energy) (Guiducci et al., 2012). Feed costs were composed unbeatable prices and quantities supplied the ingredients of diets, based on dry matter and from the results of the meta-analysis of productive data of cattle.

The indicators of economic efficiency were: total revenue (RT), total cost (TC), net income (NI), point of leveling (PL) and total factor productivity (TFP), calculated as Guiducci et al. (2012). The financial indicators considered were: net present value (NPV), annualized net present value (NPVa), term of return on investment (Payback), internal rate of return (IRR) profitability index (PI) and rate of profitability (RP), calculated as Guiducci et al. (2012). For both, were simulated cash flows for the period of ten years.

For the investment to be considered viable, the expected flow of income must be greater than the value of the investment that generated it. In other words, the NPV must be greater than zero. The profitability index was calculated to indicate the return calculated for each monetary unit invested, updated by the minimum rate of attractiveness $(6.00 \%)$.

For the realization of sensitivity analysis, the items that compose the cash flows from each system were studied individually. In this work, to perform sensitivity analysis, we adopted the discount rate of $6 \%$ per year, whereas a variation of $30 \%$, both favorable and unfavorable to the results of each system, i.e., the price of each item that compose the cash flow. From there, it was possible to observe what item had a greater effect on the indicator of economic outcome. 


\section{Ml Macrothink}

The sensitivity analysis will identify the limits within which the product price can vary without compromising the economic viability of the production system. From variations in total revenue, caused by variations in the price level (or the level of production, because of variations in productivity) the results concerning the remuneration of the entrepreneur will be affected, since changes in income affect indicators of economic efficiency and cash flow.

In order to verify that the price level (or level of production) a certain system of production is viable; it is proposed that the sensitivity analysis for indicators of economic efficiency and to the indicators relating to investment. Were established, then intervals of variations in the price received by the producer and evaluated the behavior of the indicators for each level of price and quantity produced. This interval was defined in accordance with the reality of price variations of each product in analysis, in recent years. For the cost of diets and foods were used methodologies proposed by Matsunaga et al. (1976), Resende Filho, Braga and Rodrigues (2001), Lapponi (2007), Souza and Clemente (2009) and the National Food Supply Company (NFSP, 2010). The minimum rate of attractiveness (MRA) considered to be $0.4868 \%$ months., corresponding to the income from savings of $6 \%$ year., calculated by the following equation: MRA $(\%)=(1+6 \%$ year $) 1 / 12-1$.

The facilities costs were estimated for static capacity of 500 animals and useful life of 10 years. The depreciation (installations) of same was calculated for a planning horizon of one-year, same period considered in the calculation of the depreciation of machinery, implements and equipment. The estimated values for reductions were $\mathrm{R} \$ 0.05 / \mathrm{animal} / \mathrm{day}$ with installations and R \$ 0.04/animal/day with machinery, implements and equipment. The opportunity costs were calculated considering the MRA. The costs related to the sanitary control consisted in the application of products to control Endo and ectoparasites (ivermectin $1 \%$ ). Both in the dosage per animal according to manufacturers' recommendations. The purchase price of the young bulls was $\mathrm{R} \$ 800.00$ based on the price of the cattle skinny, considered as an investment and not as cost of production and the selling price was R\$170,00 to @.

\section{Results and Discussion}

The average cost with feed per animal in the first scenario was on average $\mathrm{R} \$ 11.18 / \mathrm{head}$ day $^{-1}$. In this way, the cost to feed a flock with 1,500 animals is $\mathrm{R} \$ \$ 1,916,550.00$, being most intended for the purchase of corn silage ( $\mathrm{R} \$ 810,000.00)$ and soybean ( $\mathrm{R} \$ 572,400.00)$ which corresponds to $42.26 \%$ and $29.87 \%$, respectively. Throughout the year the quantity of feed needed to maintain 1,500 heads, independent of the variation of price is $1,800,000 \mathrm{~kg}$. Already in the other scenarios there was a variation of $\mathrm{R} \$ 1.12$ day $^{-1}$, providing a difference for more and less than $\mathrm{R} \$ 191,655.00$ in annual costs with supply. 
Table 1. Average cost of diet as the total quantity supplied (dry matter) for termination of 1,500 Nellore cattle fed with standard diet formulated based on corn and soybean meal in virtue of changing prices in Brazil

\begin{tabular}{|c|c|c|c|c|}
\hline \multirow{2}{*}{ Food } & Price $(\mathrm{Kg})$ & $\begin{array}{c}\text { Cost animal } \\
\text { day }^{-1}\end{array}$ & Annual Cost & Quantity kg year ${ }^{-1}$ \\
\hline & \multicolumn{4}{|c|}{ Price of commodities } \\
\hline Silage maize & 0.75 & 4.73 & $810,000.00$ & 1,080000 \\
\hline Maize grains & 1.06 & 2.23 & $381,600.00$ & 360,000 \\
\hline Soybean meal & 2.12 & 3.34 & $572,400.00$ & 270,000 \\
\hline Limestone & 0.47 & 0.12 & $21,150.00$ & 45,000 \\
\hline Mineral salt & 2.92 & 0.77 & $131,400.00$ & 45,000 \\
\hline \multirow[t]{2}{*}{ Total } & & 11.18 & $1,916,550.00$ & 1,800000 \\
\hline & \multicolumn{4}{|c|}{ Reduction of $10 \%$ in food } \\
\hline Silage maize & 0.68 & 4.25 & $729,000.00$ & 1,080000 \\
\hline Maize grains & 0.95 & 2.00 & $343,440.00$ & 360,000 \\
\hline Soybean meal & 1.91 & 3.01 & $515,160.00$ & 270,000 \\
\hline Limestone & 0.42 & 0.11 & $19,035.00$ & 45,000 \\
\hline Mineral salt & 2.63 & 0.69 & $118,260.00$ & 45,000 \\
\hline \multirow[t]{2}{*}{ Total } & & 10.06 & $1,724,895.00$ & $1,800.000$ \\
\hline & \multicolumn{4}{|c|}{ Increase of $10 \%$ in food } \\
\hline Silage maize & 0.83 & 5.20 & $891,000.00$ & 1,080000 \\
\hline Maize grains & 1.17 & 2.45 & $419,760.00$ & 360,000 \\
\hline Soybean meal & 2.33 & 3.67 & $629,640.00$ & 270,000 \\
\hline Limestone & 0.52 & 0.14 & $23,265.00$ & 45,000 \\
\hline Mineral salt & 3.21 & 0.84 & $144,540.00$ & 45,000 \\
\hline Total & & 12.30 & $2,108,205.00$ & 1,800000 \\
\hline
\end{tabular}

The costs with food, in percentage terms, were higher for the scenario in which increased by $10 \%$ of the supply, something that was already expected (Figure 1). However, to take a closer look at these costs can be observed that labor costs, animal welfare and maintenance of 
improvements does not correspond neither to $1 \%$ of the cost, showing something very interesting and which, to some extent, agrees with the literature, which reports that health costs is negligible, less than $2 \%$ of the total cost. This research was around $0.91 ; 0.81$ and $0.94 \%$ for the scenarios based on commodities, a reduction of $10 \%$ and an increase of $10 \%$, respectively. It is interesting to emphasize that the expenses were very low. Thus, it is justified to leave to vaccinate or perform the control of parasites, because the losses resulting from these diseases could significantly influence the outcome of the activity, something very common in animals finished on pasture. In addition, it is known that the use of health management enhances the performance of animals in cattle vaccinated, feed conversion ratio increased by $2.1 \%$ compared to non-vaccinated herds (Cull et al., 2012), with a significant impact on the economic results (Tonson \& Schroeder, 2015).

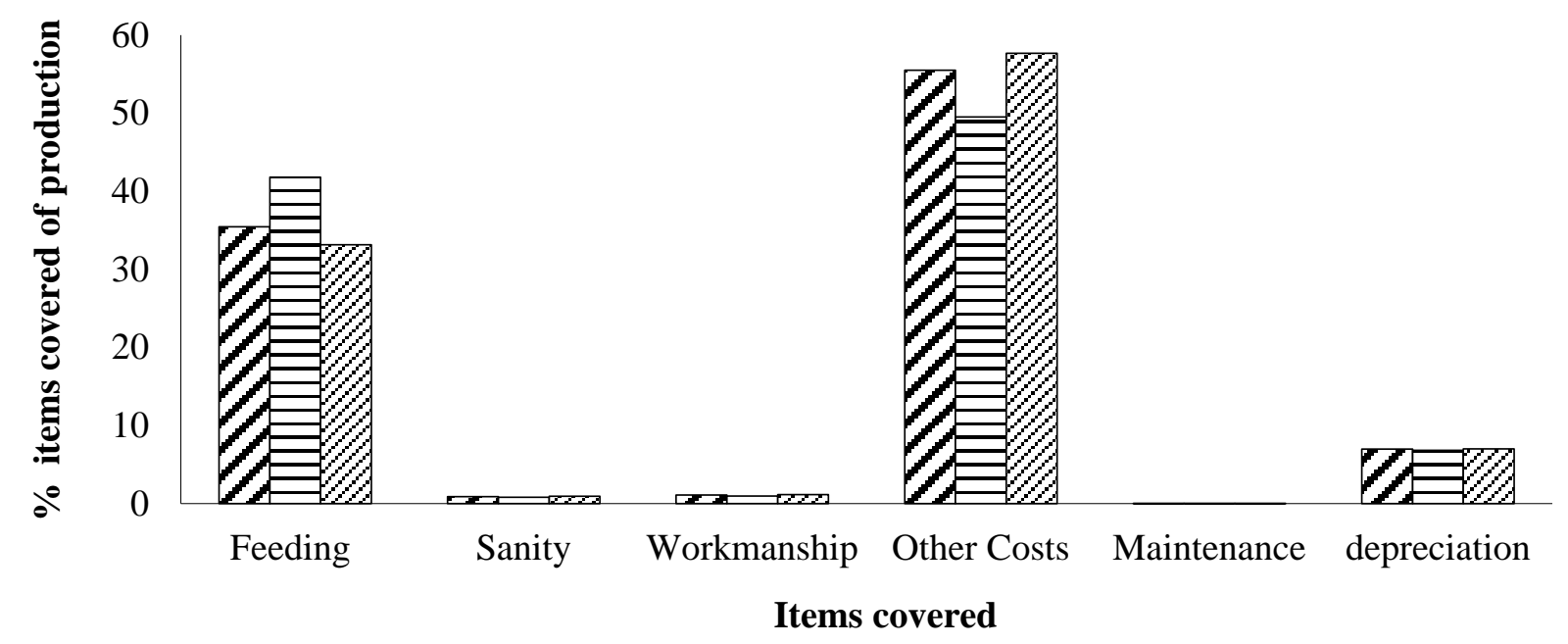

$\square$ Price of commodities $\boxminus$ Increase of $10 \% \square$ Reduction of $10 \%$

Figure 1. Annual costs for termination of 1,500 Nellore cattle fed with standard diet formulated based on corn and soybean meal in virtue of changing prices in Brazil

The annual costs for producing cattle in feedlot verified in this study corroborate with several authors (Dal Monte et al., 2010; Barros et al., 2015, Carvalho et al., 2011; Pinto et al., 2014; Stivari et al., 2014), which observed that, among the items that make up the costs of production of ruminants, in a general way, expenditure on food is one of the items of greater impact on the total cost of production. Another cost that draws attention is the depreciation of improvements.

The depreciation refers to the inclusion of rebates of values arising from effective wear of goods by the use or loss of utility, even if it is by the action of time or by simple obsolescence. It is considered a fixed value for each finished beef that was $\mathrm{R} \$ 0.05$ animal day $^{-1}$ with installations and $\mathrm{R} \$ 0.04$ animal day ${ }^{-1}$ with machines, implements and equipment. In this way, we can observe that the use of such improvements had great participation in total costs, approximately $6.98 ; 6.84$ and $7.03 \%$ for the scenarios based on commodities, a reduction of 
$10 \%$ and an increase of $10 \%$, respectively. Although the depreciation is not a disbursement, represents a cash reserve which should be available when there is a need to refit the assets (buildings, machines, equipment, etc.) at the end of its useful life. Thus, the rancher would have monetary resources to make refitting without decapitalized. The depreciation corresponded, on average, $6.95 \%$ of the total operating cost, value well above the reported by Moreira et al. (2009), Lopes \& Sampaio (1999) and Lopes \& Magalhães (2005), whose values were between $1.6 \%$ and $2.7 \%$.

We considered the price of @ negotiated in the three scenarios such as R\$ 160.00 from consulting the historical series of the Center for Advanced Studies in Applied Economics (CEPEA, 2019). Thus, it has been observed that, regardless of the change in the price of food, the revenue generated by the termination of 1,500 cattle was $R \$ 5,625,000.00$, considering that the simulations were not based on the performance of the animals (Table 2). In this way, real scenario based on the cost of commodities, the costs to produce the three lots were $\mathrm{R} \$ 5,405,033.34$, which resulted in a net income of $\mathrm{R} \$ 219,966.66$ per year, with PTF of $\mathrm{R} \$ 1.04$, i.e., for each real invested in this system there is a real return of $\mathrm{R} \$ 1.04$. On the other hand, with the increase of $10 \%$ of the costs with food, it is observed that the total costs were higher, not getting feedback, presenting negative net income ( $\mathrm{R} \$-92.621,85)$ and consequently a negative rate of return of $-1.63 \%$, considering that there was no profit. In this way, the producer would produce at least 1,524 animals to cover production costs, this leveling point shows something impossible in the situation, because the confinement has the capacity to produce up to 1,500 animals.

Table 2. Economic indicators for termination of 1,500 year ${ }^{-1}$ Nelore cattle fed with standard diet formulated based on corn and soybean meal in virtue of changing prices in Brazil

\begin{tabular}{lcccccc}
\hline \multirow{2}{*}{ Scenario } & \multicolumn{5}{c}{ Economic indicators } \\
\cline { 2 - 7 } & $\mathrm{TR}^{1}(\mathrm{R} \$)$ & $\mathrm{TC}^{2}(\mathrm{R} \$)$ & $\mathrm{NI}^{3}(\mathrm{R} \$)$ & $\mathrm{PL}^{4}$ & $\mathrm{RTe}^{5}(\%)$ & $\mathrm{TFP}^{6}$ \\
\hline Commodities & $5,625,000.00$ & $5,405,033.34$ & $219,966.66$ & 1,441 & 4.07 & 1.04 \\
Reduction of 10\% & $5,625,000.00$ & $4,835,754.00$ & $789,246.00$ & 1,289 & 16.32 & 1.16 \\
Increase of 10\% & $5,625,000.00$ & $5,717,621.85$ & $-92,621.85$ & 1,524 & -1.62 & 0.93 \\
\hline
\end{tabular}

${ }^{1} \mathrm{TR}$ : total revenue; ${ }^{2} \mathrm{TC}$ : total costs; ${ }^{3} \mathrm{NI}$ : Net Income; ${ }^{4} \mathrm{PL}$ : Point of leveling (quantity of animals terminated in order to cover the costs of production); ${ }^{5} \mathrm{RTe}$ : rate of return the entrepreneur; ${ }^{6} \mathrm{TFP}$ : total factor productivity.

On the other hand, with a reduction of $10 \%$ of the costs of supply, the containment system need only 1,289 animals and, at the same time, the TFP shall be of 1.16 and a return rate of $16.32 \%$, a value very attractive when compared to passbook savings accounts, for example, which is only $6.00 \%$ per year. You should also consider that these simulations, the only source of income is the housing of animals, but in practice this is different, because many 
systems of confinement in Brazil are selling the waste, such as animal manure. Lopes \& Magalhães (2005) reported that the sale of manure can represent up to $0.56 \%$ of the invoicing of the activity and cite that Lopes \& Sampaio (1999) found values of participation in the revenues of $2.6 \%$, and, therefore, increase of $\mathrm{R} \$ 146,250.00$ in revenue, if the dung were sold. This value would, including the net income of the pessimistic scenario (an increase of $10 \%$ in the price of commodities), were positive, something around $\mathrm{R} \$ 53,628.15$.

O The NPV for the first scenario was $\mathrm{R} \$ 4,301,680.61$, providing NPVy R $\$ 584,460.56$, IRR of 69.67 , IRRm of $150.00 \%$ and PI $110 \%$ (Table 3). These values show that the reality of national confinement is very attractive, considering that these values correspond to a margin of horizon for ten years. According to the National Association of Intensive farming ASSOCON, the production of beef in Brazil needs to grow at least $13 \%$ to compensate for the increase of $7 \%$ of domestic demand and $31 \%$ in exports until 2026. The national flock is already in the process of slowing down its growth due to the difficulty of opening up new areas for grazing. In this way, means that, increasingly, the national livestock has to learn to produce more in less area, i.e., in confinement, and these data show that over the next ten years, if the price of the @ of cattle does not very much, will be highly economically viable to produce cattle in feedlot.

In contrast, in a pessimistic scenario in which the price of commodities that are part of the feeding of animals, increase by up to $10 \%$, occurs a variation in production costs, causing the financial indicators are negative, such as NPV of R $\$-233,908.23$, drastic reduction in relation to the previous scenario Even so, the return on investment will be purchased, i.e., the payback is the time required for recovery of investment will be of 7.45 years, i.e., the period for which these negative cash flows are canceled out by the positives is too long, the current scenario has proved to be of 1.75 years and with a reduction of $10 \%$ of the commodities of 1.25 years.

Table 3. Financial indicators for termination of 1,500 year ${ }^{-1}$ Nelore cattle fed with standard diet formulated based on corn and soybean meal as a result of the change in prices in Brazil

\begin{tabular}{lcccccc}
\hline \multirow{2}{*}{ Scenario } & \multicolumn{5}{c}{ Financial indicators } \\
\cline { 2 - 7 } & NPV $^{1}$ & $\mathrm{NPVy}^{2}$ & $\mathrm{~PB}^{3}$ & $\mathrm{IRR}^{4}$ & $\mathrm{IRRm}^{5}$ & $\mathrm{PI}^{6}$ \\
\hline Commodities & $4,301,680.61$ & $584,460.56$ & 1.75 & 69.67 & 150.00 & 110.40 \\
Reduction of 10\% & $5,712,278.10$ & $776,115.56$ & 1.25 & 74.51 & 198.73 & 146.27 \\
Increase of 10\% & $-233,908.63$ & $-31,780.69$ & 7.45 & -75.00 & -10.00 & -4.94 \\
\hline
\end{tabular}

${ }^{1} \mathrm{NPV}$ : Net Present Value (U\$); ${ }^{2} \mathrm{NPVy}$ : year net present value (U\$ \$); ${ }^{3} \mathrm{~PB}$ : Payback (years); ${ }^{4}$ IRR Internal Rate of Return (\%); ${ }^{5}$ IRRm: modified internal rate of return (\%); ${ }^{6} \mathrm{PI}$ : Profitability Index (\%) 
The sensitivity analysis of compensation for the termination of Nelore cattle 1,500 year ${ }^{-1}$ (Table 4) showed that, in an environment with recovery of $30 \%$ of the price of the @ and at the same time increase of $30 \%$ in productivity, the performance indices are highly attractive, with emphasis on the payback of 0.45 years and PI of $469.21 \%$. In the simulation of the most unfavorable system, for example, the NPV was R $\$-6.430 .171,79$, with the payback of 8.02 years, i.e., too much time for the return of the investment, with negative internal rate of return of $-65,86 \%$. The profitability index was negative, showing inefficiency in this situation. showing by this point of view, that the activity is economically unviable.

Table 4. Financial sensitivity analysis for termination of 1,500 year-1 Nelore cattle fed with standard diet formulated based on corn and soybean meal in relation to the price of commodities in Brazil

\begin{tabular}{|c|c|c|c|c|c|c|}
\hline \multicolumn{2}{|c|}{ Variation } & \multicolumn{5}{|c|}{ Financial indicators } \\
\hline Price & Quantity & $\mathrm{NPV}^{1}$ & $\mathrm{NPVy}^{2}$ & $\mathrm{~PB}^{3}$ & $\mathrm{IRR}^{4}$ & $\mathrm{PI}^{5}$ \\
\hline $30 \%$ & $30 \%$ & $18,410,122.10$ & $2,501,345.69$ & 0.45 & 579.49 & 469.21 \\
\hline $20 \%$ & $20 \%$ & $14,270,073.04$ & $1,938,845.69$ & 0.68 & 436.44 & 363.92 \\
\hline $10 \%$ & $10 \%$ & $10,130,024.08$ & $1,376,345.69$ & 0.97 & 293.38 & 258.63 \\
\hline$-10 \%$ & $-10 \%$ & $1,849,926.15$ & $251,345.69$ & 1.85 & 85.89 & 48.05 \\
\hline$-20 \%$ & $-20 \%$ & $-2,290,122.82$ & $-311,154.31$ & 6.57 & -13.75 & -57.24 \\
\hline$-30 \%$ & $-30 \%$ & $-6,430,171.79$ & $-873,654.31$ & 8.02 & -65.86 & -162.53 \\
\hline
\end{tabular}

${ }^{1} \mathrm{NPV}$ : Net Present Value (R\$); ${ }^{2} \mathrm{NPVy}$ : year net present value (R\$); ${ }^{3} \mathrm{~PB}$ : Payback (years); ${ }^{4}$ IRR Internal Rate of Return (\%); ${ }^{5}$ PI: Profitability Index (\%).

In the scenario where there is a reduction of $10 \%$ of the price of commodities (Table 5), we can observe that even in a simulation in which there is a reduction of $10 \%$ in the price and quantity produced, the indicators of economic viability have been positive. In this case, the NPV (R\$3,260,523.63) and the high IRR (56.14\%), with PB of 1.20 years, pointing out that even so this system can remain viable form in an adverse situation. Already in an environment with greater appreciation, the NPV is R $\$ 19,820,719.50$, with PB of 0.51 years, and the profitability index of $505.09 \%$, showing that the increase of $30 \%$ in prices this scenario is very attractive. 
Table 5. Financial sensitivity analysis for termination of 1,500 year ${ }^{-1}$ Nelore cattle fed with standard diet formulated based on corn and soybean meal in relation to reduction of $10 \%$ in the price of commodities in Brazil

\begin{tabular}{cccccccc}
\hline \multicolumn{2}{c}{ Variation } & & \multicolumn{5}{c}{ Financial indicators } \\
\cline { 1 - 5 } \cline { 5 - 7 } Price & Quantity & & $\mathrm{NPV}^{1}$ & $\mathrm{NPVy}^{2}$ & $\mathrm{~PB}^{3}$ & $\mathrm{IRR}^{4}$ & $\mathrm{PI}^{5}$ \\
\hline $30 \%$ & $30 \%$ & & $19,820,719.50$ & $2,693,000.69$ & 0.51 & 628.24 & 505.09 \\
$20 \%$ & $20 \%$ & & $15,680,670.53$ & $2,130,500.69$ & 0.65 & 485.18 & 399.79 \\
$10 \%$ & $10 \%$ & & $11,540,621.56$ & $1,568,000.69$ & 0.70 & 342.12 & 294.50 \\
$-10 \%$ & $-10 \%$ & & $3,260,523.63$ & $443,000.69$ & 1.20 & 56.14 & 83.92 \\
$-20 \%$ & $-20 \%$ & & $-879,525.34$ & $-119,449.31$ & 5.87 & -1.24 & -21.37 \\
$-30 \%$ & $-30 \%$ & & $-5,019,574.30$ & $-681,999.31$ & 6.02 & -15.76 & -126.66 \\
\hline
\end{tabular}

${ }^{1} \mathrm{NPV}$ : Net Present Value (R\$); ${ }^{2} \mathrm{NPVy}$ : year net present value (R\$); ${ }^{3} \mathrm{~PB}$ : Payback (years); ${ }^{4}$ IRR Internal Rate of Return (\%); ${ }^{5} \mathrm{PI}$ : Profitability Index (\%).

The sensitivity analysis of production of feedlot with an increase of $10 \%$ in the price of food showed a greater variation (Table 6). We observed that in the simulation of a more pessimistic scenario, i.e., with a reduction of $30 \%$ as much of production as the price of the product, the internal rate of return was of $-0,83 \%$ and payback more than ten years, making the system highly inefficient. In fact, only with a reduction of $10 \%$ of the price of the product and quantity produced, the system has become inefficient, with NPV of R $\$-2,685,663.10$ and payback of 8.97 years.

Table 6. Financial sensitivity analysis for termination of 1,500 year ${ }^{-1}$ Nelore cattle fed with standard diet formulated based on corn and soybean meal in relation to the increase of $10 \%$ in the price of commodities in Brazil

\begin{tabular}{cccccccc}
\hline \multicolumn{2}{c}{ Variation } & & \multicolumn{5}{c}{ Financial indicators } \\
\cline { 1 - 5 } \cline { 5 - 7 } Price & Quantity & & $\mathrm{NPV}^{1}$ & $\mathrm{NPVy}^{2}$ & $\mathrm{~PB}^{3}$ & $\mathrm{IRR}^{4}$ & $\mathrm{PI}^{5}$ \\
\hline $30 \%$ & $30 \%$ & & $13,874,532.77$ & $1,885,04.44$ & 2.24 & 112.98 & 253.86 \\
$20 \%$ & $20 \%$ & & $9,734,483.80$ & $1,322,604.44$ & 2.42 & 97.98 & 148.571 \\
$10 \%$ & $10 \%$ & & $5,594,434.83$ & $760,104.44$ & 2.64 & 54.98 & 103.280 \\
$-10 \%$ & $-10 \%$ & & $-2,685,663.10$ & $-364,895.56$ & 8.97 & -16.27 & -67.30 \\
$-20 \%$ & $-20 \%$ & & $-6,825,712.07$ & $-927,395.56$ & -- & -43.98 & -172.59 \\
$-30 \%$ & $-30 \%$ & & $-10,965,761.03$ & $-1,489,895.56$ & -- & -89.67 & -277.88 \\
\hline
\end{tabular}


${ }^{1} \mathrm{NPV}$ : Net Present Value (R\$); ${ }^{2} \mathrm{NPVy}$ : year net present value (R\$); ${ }^{3} \mathrm{~PB}$ : Payback (years); ${ }^{4}$ IRR Internal Rate of Return (\%); ${ }^{5}$ PI: Profitability Index (\%).

On the basis of current performance data, is highly profitable produce Nellore cattle in feedlot Brazil, except with an increase of $10 \%$ in the price of commodities and, consequently, the feeding of animals confined. It should be emphasized that the creation of animals requires a large investment, which can hamper the expansion of this type of system. However, if the prices do not increase over the period analyzed, the evaluated systems feature fast return on investment applied.

\section{Conclusions}

Sensitivity analyzes showed that, in the current situation, only in the most unfavorable situations, such as reductions of 20 and $30 \%$ in both production and market price, the economic performance indicators were not attractive, given that the time of return on investment is very long, with the exception in the reduction of $10 \%$ of production and price, that are economically viable. The same thing would happen in an environment in which there is a reduction of $10 \%$ in the price of commodities and food, but with minor economic impacts. On the other hand, in the scenario with an increase of $10 \%$ in the price of commodities, a simple reduction of $10 \%$ of the price of @ and the quantity produced makes the system economically inefficient.

\section{References}

ABIEC. Associação Brasileira de Indústrias Exportadoras de Carne. Perfil da Pecuária no Brasil. Diponível em: http://www.abiec.com.br/controle/uploads/arquivos/sumario2019portugues.pdf

Barros, M. C. C., Marques, J. A., Silva, R. R., Silva, F. F., Costa, L. T., Guimarâes, S., ... Gusmão, J. J. N. (2015). Economic viability of crude glycerin in diets for lambs finished in feedlot. Semina: Ciências Agrárias. 36(5), 443-452. https://doi.org/10.5433/1679-0359.2015v36n1p443

Dal Monte, H. L., Costa, R. G., Holanda Júnior, E. V., Pimenta Filho, E. C., Cruz, G. R. R., \& Menezes, M. P. C. (2010). Calculation of the costs and evaluation of incomes in different systems of production of goat milk in Cariris Paraibanos. Revista Brasileira de Zootecnia, $39(11), 2535-2544$.

Guiducci, R. C. N., Alves, E. R. A., Lima Filho, J. R., \& Mota, M. M. (2012). Aspectos metodológicos da análise de viabilidade econômica de sistemas de produção. In: Guiducci, $\mathrm{R}$. C. N., Lima Filho, J. R. \& Mota, M. M. (Ed.). Viabilidade econômica de sistemas de produção agropecuários: metodologia e estudos de caso. Brasília, DF: Embrapa. p. 17-78.

Imbeau, L. M., Pétry, F., \& Lamari, M. (2001). Left-right party ideology and government policies: A meta-analysis. European Journal of Political Research, 23(9), 34-45. https://doi.org/10.1111/1475-6765.00587

Lopes, L. S., Ladeira, M. M., Machado Neto, O. R., Silveira, A. R. M. C., Reis, R. P., \& 
Campos, F. R. (2011). Viabilidade econômica da terminação de novilhos nelore em confinamento na região de Lavras-MG. Ciência e Agrotecnologia, 35(4), 774-780. https://doi.org/10.1590/S1413-70542011000400017

Lopes, M. A., \& Carvalho, F. M. Custo de produção do gado de corte. Disponível em : http://www.editora.ufla.br/BolTecnica?pdf/bol_47.pdf

Lopes, M. A., \& Magalhães, G. P. (2005). Rentabilidade na terminação de bovinos de corte em condições de confinamento: um estudo de caso em 2003, na região oeste de Minas Gerais. Ciência e Agrotecnologia, 29(5), 1039-1044.

https://doi.org/10.1590/S1413-70542005000500019

Lopes, M. A., Santos, G., Rosa, L. V., \& Lopes, N. M. (2005). Rentabilidade da terminação em confinamento de bovinos de corte castrados e não castrados. Boletim de Indústria Animal. 62(4), 289-294.

Moreira, S. A., Thomé, K. M., Ferreira, P. S., \& Botelho Filho, F. B. (2009). Análise econômica da terminação de gado de corte em confinamento dentro da dinâmica de uma propriedade agrícola. Custos e @ gronegócio online, 5(3), 132-152.

Paim, T. P., Cardoso, M. T. M., Borges, B. O., Gomes, E. F., Louvandini, H., \& MCManus, C. (2011). Estudo econômico da produção de cordeiros cruzados confinados abatidos em diferentes pesos. Ciência Animal Brasileira, 12(5), 48-57. https://doi.org/10.5216/cab.v12i1.5894

Pinto, C. W. C., Costa, J. M. O., \& Nobrega JR, J. E. (2014). Alternativa para produção de cordeiros Santa Inês em confinamento, alimentados com subprodutos da agroindústria. Revista Agropecuária Técnica. 35(4), 185-190.

Santos, G., \& Lopes, M. A. (2014). Indicadores econômicos de sistemas de produção de leite em confinamento total com alto volume de produção diária. Ciência Animal Brasileira, 15(3), 239-248. https://doi.org/10.1590/1809-6891v15i314045

Santos, R. A., Souza, T. L., \& Braga Filho, R. (2011). Um estudo sobre a viabilidade econômica da criação de gado leiteiro numa propriedade com arrendamento rural para auxiliar na criação de gado de corte - estudo de caso. Revista Eletrônica Saber Contábil, $1(1), 56-73$.

Silva, M. C., Boaventura, V. M., \& Fioravanti, M. C. S. (2012). História do povoamento bovino no Brasil Central. Revista UFG, 13, 34-41.

Souza, A. \& Clemente, A. Decisões financeiras e análise de investimentos. 5. ed. São Paulo: Atlas, 2004. 178 p.

Stivari, T. S. S., Chen, R. F. F., Gameiro, A. H., Monteiro, A. L. G., Raineri, C., \& Silva, J. B. A. (2014). Feasibility of grazing sheep production systems using long-term economic indicators and the methodology of the soil expectation value. Brazilian Journal of Veterinary $\begin{array}{llrr}\text { Research Animal } \quad \text { Science, } & \text { 51(12), }\end{array}$ https://doi.org/10.11606/issn.1678-4456.v51i2p149-157 


\section{Macrothink}

Journal of Agricultural Studies

ISSN 2166-0379

2020, Vol. 8, No. 4

ST-Pierre, N. R., \& Cobanov, B. (2007). A model to determine the optimal sampling schedule of diet components. Journal of Dairy Science. 90, 5383-5394. https://doi.org/10.3168/jds.2006-727

\section{Copyright Disclaimer}

Copyright for this article is retained by the author(s), with first publication rights granted to the journal.

This is an open-access article distributed under the terms and conditions of the Creative Commons Attribution license (http://creativecommons.org/licenses/by/4.0/). 